\title{
DAMPAK PERUBAHAN PAJAK IMPOR INDIA DAN KAPASITAS PRODUKSI INDUSTRI HILIR MINYAK SAWIT MENTAH INDONESIA TERHADAP DAYA SAING DAN PENERIMAAN DEVISA INDONESIA
}

\section{Impact of Change in Indian Import Tax and Production Capacity of Indonesian Crude Palm Oil Downstream Industries on Indonesia's Competitiveness and Foreign Exchange Revenues}

\author{
Novindra', Bonar M. Sinaga ${ }^{1}$, Sri Hartoyo ${ }^{2}$, Erwidodo ${ }^{3}$ \\ ${ }^{1}$ Departemen Ekonomi Sumberdaya dan Lingkungan, Fakultas Ekonomi dan Manajemen, IPB \\ 2 Departemen IImu Ekonomi, Fakultas Ekonomi dan Manajemen, IPB \\ $1,2 \mathrm{JI}$. Agatis Kampus IPB Dramaga, Babakan, Dramaga, Bogor, Jawa Barat 16680, Indonesia \\ ${ }^{3}$ Pusat Sosial Ekonomi dan Kebijakan Pertanian, Badan Penelitian dan Pengembangan Pertanian, \\ Kementerian Pertanian Republik Indonesia, Jl. Tentara Pelajar No. 3B Ciwaringin, \\ Bogor, Jawa Barat 16111, Indonesia \\ Email: novindra@apps.ipb.ac.id
}

Naskah diterima: 14/12/2019; Naskah direvisi: 15/08/2020; Disetujui diterbitkan: 04/03/2021; Dipublikasikan online: 15/07/2021

\begin{abstract}
Abstrak
India meningkatkan pajak impor CPO menyebabkan ekspor CPO Indonesia turun sehingga penerimaan devisa dari ekspor CPO juga menurun. Indonesia seharusnya tidak terus bergantung pada devisa dari ekspor CPO, apalagi Indonesia masih mengimpor produk turunan CPO. Indonesia harus terus menumbuhkembangkan industri hilir CPO yang lebih besar menghasilkan nilai tambah dan devisa. Oleh karena itu, perlu kebijakan pemerintah yang tepat guna mendukung hilirisasi industri CPO. Artikel ini bertujuan untuk: (1) menganalisis faktor-faktor yang memengaruhi impor CPO India; harga ekspor CPO Indonesia ke India; harga domestik CPO dan permintaan CPO oleh industri minyak goreng sawit, margarin, dan sabun; dan (2) mengevaluasi dampak peningkatan pajak impor CPO India dan kapasitas produksi industri hilir CPO terhadap daya saing ekspor CPO Indonesia-Malaysia, minyak goreng sawit, margarin dan sabun Indonesia serta penerimaan devisa ekspor CPO, minyak goreng sawit, margarin, dan sabun Indonesia periode 2015-2017. Artikel ini merupakan bagian dari penelitian tentang penawaran dan permintaan minyak sawit dan produk turunan yang menggunakan model ekonometrika yaitu: sistem persamaan simultan dinamis. Peningkatan harga CPO dunia akan berpengaruh besar terhadap harga ekspor CPO Indonesia ke India. Peningkatan kapasitas produksi industri hilir CPO akan berpengaruh besar terhadap permintaan CPO dan produksi produk turunannya. Untuk meningkatkan daya saing dan nilai penerimaan devisa ekspor produk turunan CPO Indonesia, pada kondisi India atau negara importir utama lainnya meningkatan pajak impor CPO maka pemerintah perlu memfasilitasi peningkatan kapasitas produksi industri hilir CPO dan produksi produk turunan CPO di Indonesia.
\end{abstract}

Kata Kunci: Pajak Impor CPO, Permintaan CPO, Devisa, Ekonometrika, Simulasi

\begin{abstract}
India increased the CPO import tax rate causing Indonesia's CPO exports to fall so that foreign exchange revenues from CPO exports also declined. Indonesia should not continue to depend on these, especially since Indonesia still imports CPO-derived products. Indonesia must continue to develop CPO downstream industries that larger producing added value and foreign exchange revenues. The right government policies are needed to support development the CPO downstreaming industries. This article aims to: (1) analyze the factors affecting Indian CPO imports; Indonesian CPO export prices to India; CPO domestic prices and CPO demand by the palm cooking oil, margarine, and soap industries; and (2) evaluating the impact of an
\end{abstract}


increase in Indian CPO import tax rate and production capacity of CPO downstream industries on the competitiveness of Indonesia-Malaysia CPO exports, Indonesian exports of palm cooking oil, margarine and soap as well as Indonesian foreign exchange revenues in 20152017 period. This article is part of a research on the supply and demand of palm oil and its derivatives using the econometric model: dynamic simultaneous equation systems. The increase in world CPO prices will have a major effect on the export price of Indonesian CPO to India. The increase in the production capacity of the CPO downstream industry will have a major impact on the demand for CPO and the production of its derivative products. To increase the competitiveness and the value of foreign exchange earnings from Indonesian exports of CPO derivative products, in conditions of India or other major importing countries to increase CPO import taxes rate, government are needed to facilitate increasing in production capacity of the CPO downstream industry and the production of CPO derivative products in Indonesia.

Keywords: CPO Import Taxes, Demand for CPO, Foreign Exchange, Econometric, Simulation

JEL Classification: C32, C53, D24, F13, F17, Q17

\section{PENDAHULUAN}

Indonesia merupakan negara produsen minyak sawit terbesar di dunia sejak tahun 2006. Dalam kurun waktu 2014-2018, rata-rata produksi minyak sawit Indonesia sebesar 34,42 juta ton dengan pangsa $53,94 \%$ dari produksi minyak sawit dunia sedangkan rata-rata produksi minyak sawit Malaysia sebesar 19,41 juta ton dengan pangsa $30,42 \%$ dari produksi minyak sawit dunia. Ratarata produksi minyak sawit dunia adalah 63,82 juta ton (Oil World, 2018).

Selain itu, Indonesia juga merupakan negara pengekspor minyak sawit mentah (crude palm oillCPO) terbesar di dunia sejak tahun 2008, yang sebelumnya dipimpin oleh Malaysia. Periode 2014-2018, diketahui rata-rata ekspor CPO dunia sebesar 14,86 juta ton. Rata-rata ekspor CPO Indonesia ke dunia sebesar 6,49 juta ton (pangsa 43,65\% ) sedangkan rata-rata ekspor CPO Malaysia ke dunia sebesar 4,01 juta ton (pangsa 26,97\% ) (UN Comtrade, 2019).

Prospek masa depan CPO sangat cerah dan menjadi komoditas primadona bagi Indonesia, Malaysia dan produsen CPO lainnya karena dapat mensubstitusikan minyak nabati lainnya dengan lebih efisien. Hal ini ditunjukkan dengan produktivitas ratarata dunia dari kelapa sawit adalah 3,96 ton minyak per hektar per tahun (4-8 kali per hektar lebih besar dibandingkan produktivitas minyak nabati lainnya) sehingga jika ada peningkatan permintaan minyak nabati dunia sebesar 51 juta ton dapat dipenuhi dari 13 juta ha lahan baru kelapa sawit (Sitanggang, 2018).

Rata-rata laju pertumbuhan impor CPO di dunia selama 2007-2018 
sebesar 3,38\%. Pada tahun 2007 impor CPO di dunia sebesar 10.827,62 ribu ton, kemudian tahun-tahun berikutnya impor CPO dunia mengalami fluktuasi, hingga tahun 2018 impor CPO di dunia sebesar 14.242,85 ribu ton (UN Comtrade, 2019). Adanya permintaan CPO di dunia yang cenderung meningkat mendorong pengusaha CPO Indonesia terus meningkatkan produksi CPO guna meningkatkan ekspornya. Selain itu selama 2007-2018, rata-rata laju pertumbuhan harga CPO dunia sebesar 2,69\% (World Bank, 2019).

Menurut Novindra (2011) alasan pengusaha CPO Indonesia terus meningkatkan ekspor CPO diantaranya karena peningkatan harga CPO di pasar dunia dan terdepresiasinya mata uang rupiah terhadap mata uang dollar AS. Rata-rata laju pertumbuhan produksi CPO Indonesia dari tahun 2007 hingga tahun 2018 adalah sebesar 7,86\%. Pada tahun 2007 jumlah produksi CPO Indonesia sebesar $17.796,37$ ribu ton, kemudian terus meningkat hingga menjadi $40.567,23$ ribu ton tahun 2018
(Ditjenbun Kementerian Pertanian, 2019).

Selama periode 1998-2009, peningkatan produksi CPO Indonesia selalu diikuti peningkatan ekspor CPO Indonesia. Rata-rata laju pertumbuhan produksi CPO Indonesia sebesar $13,02 \%$ dan rata-rata laju pertumbuhan ekspor CPO Indonesia sebesar $37,79 \%$. Namun sejak tahun 2010 hingga tahun 2018, jumlah ekspor CPO Indonesia ke pasar dunia mengalami penurunan (kecuali tahun 2015 dan 2017). Diketahui bahwa selama periode 20102018, rata-rata laju pertumbuhan produksi CPO Indonesia sebesar 7,46\% sedangkan rata-rata laju penurunan ekspor CPO Indonesia sebesar 1,98\% (UN Comtrade, 2019 dan Ditjenbun Kementerian Pertanian, 2019). Hal ini terjadi karena adanya peningkatan permintaan CPO oleh industri hilir CPO di Indonesia dengan rata-rata laju pertumbuhan $8,97 \%$ selama 2010-2018 (Oil World, 2018). Gambar 1 menunjukkan perkembangan produksi $\mathrm{CPO}$, ekspor CPO dan permintaan CPO Indonesia selama 1998-2018. 


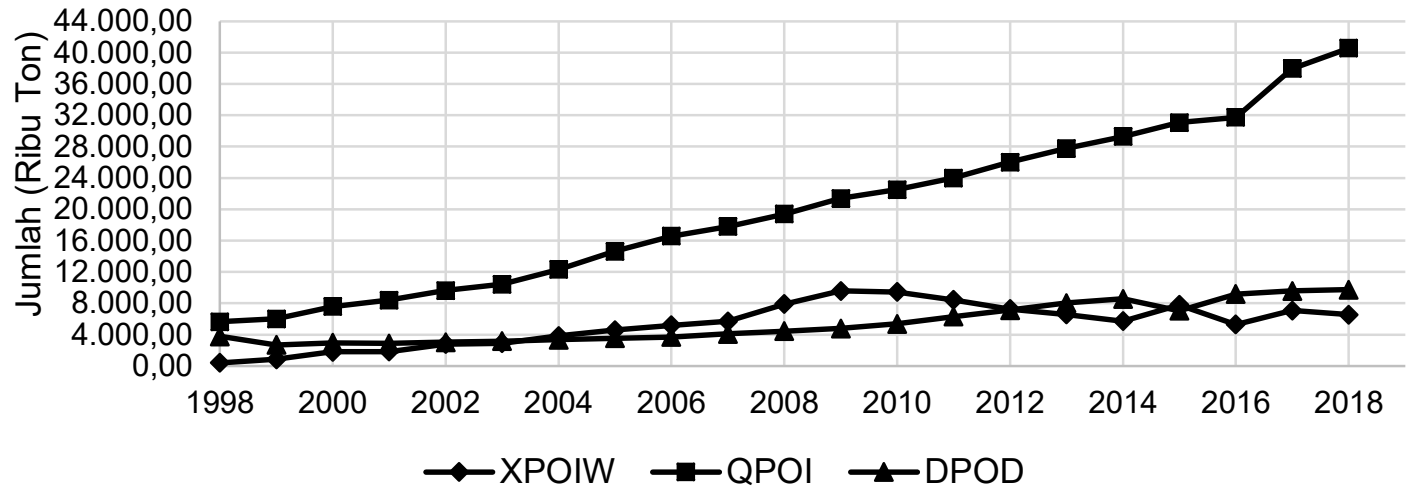

Gambar 1. Jumlah Produksi CPO, Ekspor CPO, dan Permintaan CPO Indonesia Periode 1998-2018

Sumber: Ditjenbun Kementerian Pertanian (2019); UN Comtrade (2019); Oil World (2018)

Keterangan:

XPOIW : Jumlah ekspor CPO Indonesia ke pasar dunia

QPOI : Jumlah produksi CPO Indonesia

DPOD : Jumlah permintaan CPO Indonesia

Selama periode 2007-2018, diketahui bahwa tiga negara utama tujuan ekspor CPO Indonesia yaitu India, Belanda dan Singapura. Rata-rata jumlah ekspor CPO Indonesia ke pasar dunia sebesar 7.275,63 ribu ton, India sebesar $3.727,91$ ribu ton $(51,24 \%)$, Belanda 847,67 ribu ton $(11,65 \%)$, dan Singapura 561,19 ribu ton $(7,71 \%)$. Selanjutnya, diketahui bahwa selama periode 2007-2018 jumlah ekspor CPO Indonesia ke India dan Belanda berfluktuasi, dengan rata-rata laju pertumbuhan ekspor CPO Indonesia ke India sebesar $6,23 \%$ dan Belanda sebesar $6,40 \%$, begitu pula jumlah ekspor CPO Indonesia ke Singapura berfluktuasi namun dengan rata-rata laju penurunan ekspor sebesar $0,39 \%$ (UN Comtrade, 2019).
Selama periode 2016-2018, jumlah ekspor CPO Indonesia ke India mengalami fluktuasi. Ketika India menetapkan penurunan pajak impor CPO dari sebesar 12,5\% tahun 2016 menjadi sebesar $7,5 \%$ tahun 2017 , ini menyebabkan jumlah ekspor CPO Indonesia meningkat dari sebesar 2.948,98 ribu ton tahun 2016 menjadi 4.627,68 ribu ton tahun 2017. Sebaliknya, ketika India menaikkan pajak impor CPO-nya menjadi $44 \%$ pada tahun 2018 menyebabkan penurunan jumlah ekspor CPO Indonesia ke India menjadi sebesar 4.011,72 ribu ton tahun 2018 (UN Comtrade, 2019 dan WTO, 2019). Perkembangan jumlah ekspor CPO Indonesia ke pasar dunia, India, 
Belanda dan Singapura selama 20072018 ditunjukkan pada Gambar 2.

Penurunan jumlah ekspor CPO Indonesia ke India yang merupakan pengimpor terbesar (pangsa 51,24\%) menunjukkan adanya penurunan penerimaan devisa dari ekspor CPO. Sejalan hasil Purba (2019) bahwa kebijakan peningkatan tarif impor minyak sawit oleh negara importir (India,
Uni Eropa, China dan Amerika Serikat) berdampak menurunkan nilai ekspor minyak sawit. Adapun menurut Nurcahyani et al. (2018), laju pertumbuhan ekspor CPO Indonesia ke India berfluktuasi dan volume ekspor CPO Indonesia ke India dipengaruhi bea keluar CPO Indonesia secara negatif dan signifikan dalam jangka panjang dan jangka pendek.

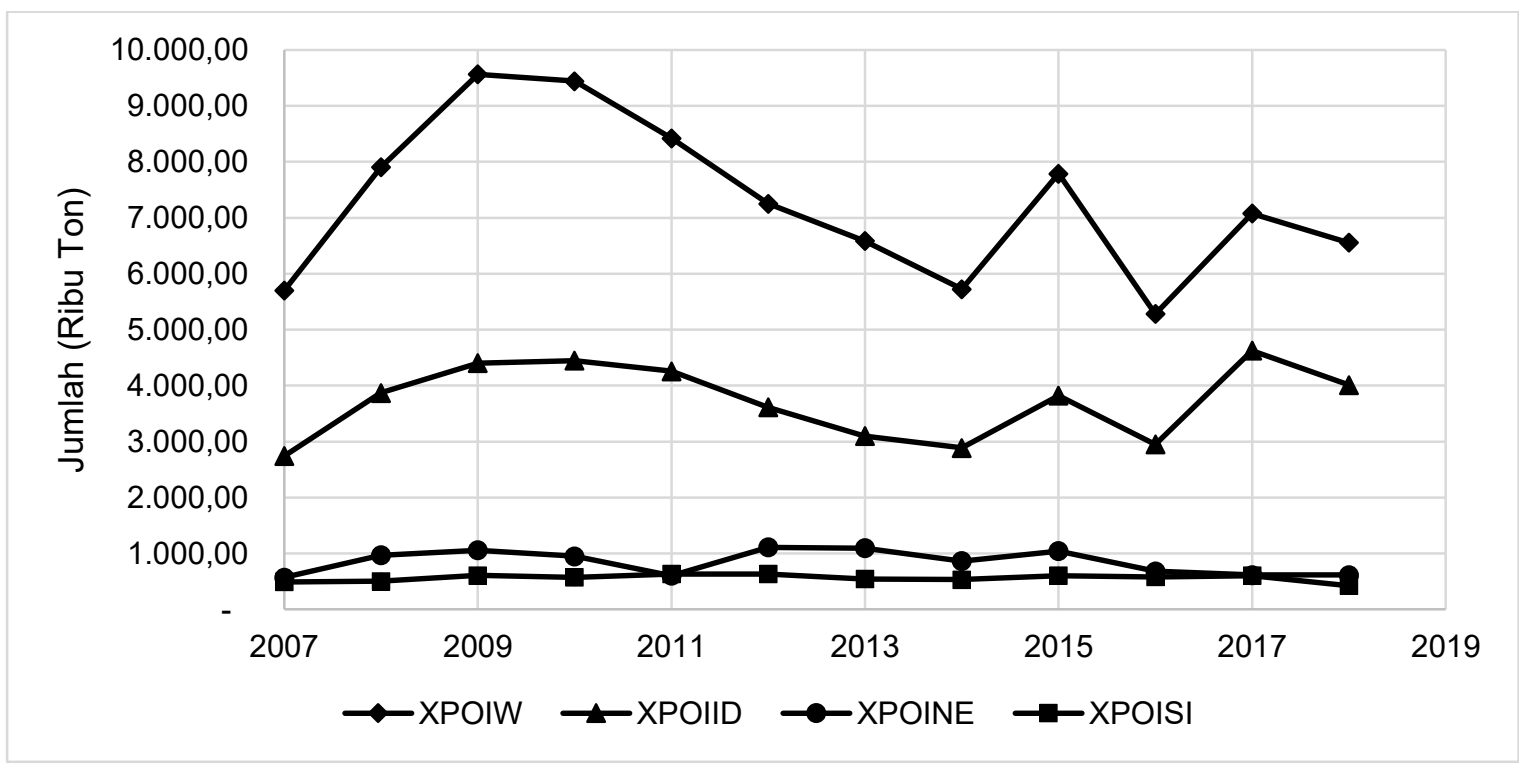

Gambar 2. Jumlah Ekspor CPO Indonesia ke Pasar Dunia dan Tiga Negara Importir Utama Periode 2007-2018

Sumber: UN Comtrade (2019)

Keterangan:

XPOIW : Jumlah ekspor CPO Indonesia ke pasar dunia

XPOIID : Jumlah ekspor CPO Indonesia ke India

XPOINE : Jumlah ekspor CPO Indonesia ke Belanda

XPOISI : Jumlah ekspor CPO Indonesia ke Singapura

Indonesia masih bergantung pada CPO guna menghasilkan produk perolehan nilai devisa dari ekspor CPO, bernilai tambah sangat besar dalam selain itu Indonesia juga masih rangka memenuhi kebutuhan domestik mengimpor produk turunan CPO. dan untuk diekspor. Peningkatan Pentingnya pengembangan industri hilir produksi industri hilir CPO dapat 
menghemat devisa (karena mengurangi impor produk turunan CPO) dan menghasilkan nilai devisa yang lebih besar (karena ekspor produk turunan CPO) (Novindra et al., 2013). Diketahui selama 2010-2018, bahwa rata-rata jumlah ekspor minyak goreng sawit, margarin dan sabun Indonesia ke pasar dunia masing-masing adalah 13.028,06 ribu ton, 89,07 ribu ton, dan 283,57 ribu ton. Sementara rata-rata jumlah impor minyak goreng sawit, margarin, dan sabun Indonesia dari pasar dunia masing-masing adalah 13,40 ribu ton, 2,30 ribu ton, dan 7,28 ribu ton (UN Comtrade, 2019).

Selain itu pada tahun 2015, Indonesia baru mampu menghasilkan 169 jenis produk turunan CPO di segmen pangan, kimia dan energi terbarukan (Ditjen Industri Agro, 2015 dan Simanjuntak, 2014). CPO dapat diolah menjadi lebih dari 300 jenis produk turunan untuk segmen pangan, kimia dan energi terbarukan, termasuk biodiesel (Simanjuntak, 2014). Tahun 2016 kapasitas produksi industri oleokimia dasar di Indonesia baru mencapai 1,6 juta ton sedangkan kapasitas produksi industri oleokimia dasar di Malaysia mencapai dua kali lipat dari Indonesia (GAPKI, 2017 dan BPPMD, 2010). Hal ini menunjukkan bahwa perkembangan investasi industri hilir CPO Indonesia masih rendah ditunjukkan dengan jumlah jenis produk dan kapasitas produksi industri hilir CPO yang masih harus ditingkatkan.

Rata-rata produksi CPO Indonesia adalah sebesar $33.773,83$ ribu ton yang berarti hampir empat kali lebih besar daripada rata-rata permintaan CPO di Indonesia sebesar $8.968,67$ ribu ton periode 2013-2018 (Ditjenbun Kementerian Pertanian, 2019 dan CIC, 2019). Hal ini berarti permintaan CPO di pasar domestik masih harus terus ditingkatkan. Selain itu, peningkatan pajak impor CPO oleh India menyebabkan penurunan ekspor CPO Indonesia.

Oleh karena itu diperlukan kebijakan pemerintah yang dapat meningkatkan permintaan CPO di pasar domestik. Kebijakan tersebut diharapkan menjadi solusi alternatif dalam menghadapi kebijakan tarif maupun non tarif dari negara importir CPO utama dunia, seperti peningkatan tarif impor CPO oleh India.

Berdasarkan latar belakang dan permasalahan, perlu dilakukan analisis kebijakan pemerintah yang tepat dalam rangka menghadapi peningkatan tarif impor CPO oleh importir India dan juga mendukung pengembangan industri hilir 
CPO di Indonesia. Tujuan penulisan artikel ini adalah: (1) untuk menganalisis faktor-faktor yang memengaruhi impor CPO India dari pasar dunia; harga ekspor CPO Indonesia ke India; harga domestik CPO dan permintaan CPO oleh industri minyak goreng sawit, margarin, dan sabun, dan (2) untuk mengevaluasi dampak peningkatan pajak impor CPO India dan kebijakan fasilitasi peningkatan kapasitas produksi industri minyak goreng sawit, margarin, sabun dan lainnya di Indonesia terhadap daya saing ekspor CPO Indonesia-Malaysia dan daya saing ekspor minyak goreng sawit, margarin dan sabun dan penerimaan devisa ekspor CPO, minyak goreng sawit, margarin dan sabun Indonesia periode 2015-2017.

\section{METODE}

$$
\begin{aligned}
& \text { Berdasarkan tujuan penelitian } \\
& \text { maka diformulasikan model } \\
& \text { ekonometrika untuk menjawab tujuan } \\
& \text { penelitian. Spesifikasi atau formulasi } \\
& \text { model dibangun berdasarkan modifikasi } \\
& \text { model dari (Novindra, 2011), teori } \\
& \text { ekonomi dan pengalaman empiris dalam } \\
& \text { membangun model ekonomi sawit. } \\
& \text { Berikut adalah spesifikasi model } \\
& \text { berdasarkan tujuan penelitian, setelah } \\
& \text { melalui beberapa tahapan respesifikasi } \\
& \text { model: }
\end{aligned}
$$

\begin{tabular}{|c|c|}
\hline MPOIDWt & $\begin{array}{l}\text { Impor CPO India } \\
\text { tahun t (000 ton) }\end{array}$ \\
\hline PRMPOIDW & $\begin{array}{l}\text { Harga riil impor } \\
\text { CPO India tahun } \\
\text { t-1 (USD/ton) }\end{array}$ \\
\hline $\mathrm{PRCOW}_{\mathrm{t}-1}$ & $\begin{array}{l}\text { Harga riil minyak } \\
\text { mentah dunia } \\
\text { tahun t-1 } \\
\text { (USD/barrel) }\end{array}$ \\
\hline PRSOW $_{\mathrm{t}-1}$ & $\begin{array}{lr}\text { Harga riil } & \text { minyak } \\
\text { kedele } & \text { dunia } \\
\text { tahun } & \mathrm{t}-1 \\
\text { (USD/ton) } & \end{array}$ \\
\hline DNBMPOIDt & $\begin{array}{l}\text { Dummy } \\
\text { Hambatan Non } \\
\text { Tarif Impor CPO } \\
\text { oleh India } \\
(1=\text { ada, } 0=\text { tidak } \\
\text { ada) }\end{array}$ \\
\hline TREN & Tren Waktu \\
\hline MPOIDW & $\begin{array}{l}\text { Impor } \text { CPO India } \\
\text { tahun t-1 }(000 \\
\text { ton) }\end{array}$ \\
\hline$U 1_{t}$ & $\begin{array}{l}\text { Variabel } \\
\text { pengganggu }\end{array}$ \\
\hline
\end{tabular}

\section{Impor CPO India}

MPOIDW $_{t}=a_{0}+a_{1}$. PRMPOIDW $_{t-1}+$ $a_{2} \cdot$ PRCOW $_{t-1}+a_{3} \cdot$ PRSOW $_{t-1}+$

$a_{4}$. DNBMPOID $+a_{5}$. TREN +

$a_{6} \cdot M^{\prime}$ OIDW $W_{t-1}+U 1_{t}$

Tanda dan besaran parameter estimasi yang diharapkan:

$a_{1}, a_{4}<0 ; a_{2}, a_{3}, a_{5}>0 ; 0<a_{6}<1$

\section{Harga Impor CPO India}

PRMPOIDW $_{\mathrm{t}}=$ PRPOW $_{t} \cdot\left(1+\right.$ TMPOID $\left._{t} / 100\right)$

PRMPOIDW $_{t}$ : Harga riil impor CPO India tahun $\mathrm{t}$ (USD/ton)

PRPOW $_{t}$ : Harga riil CPO dunia tahun $\mathrm{t}$ (USD/ton) 
TMPOID $_{t} \quad$ : Pajak impor CPO India tahun $\mathrm{t}(\%)$

Total Impor CPO di Pasar Dunia

$\mathrm{MPOW}_{\mathrm{t}}=\mathrm{MPOIDW}_{\mathrm{t}}+\mathrm{MPORW}_{\mathrm{t}}$

MPOW $_{t}$ : Total impor CPO di pasar dunia tahun $\mathrm{t}$ (000 ton)

MPOIDWt : Impor CPO India dari Pasar Dunia tahun $\mathrm{t}$ (000 ton)

MPORW $_{t}$ : Impor CPO negara importir lainnya dari Pasar Dunia tahun $\mathrm{t}$ (000 ton)

Harga Ekspor CPO Indonesia ke India PRXPOIID $\mathrm{D}_{\mathrm{t}}=\mathrm{b}_{0}+\mathrm{b}_{1}$. PRPOW $_{t}+$ $b_{2}$. (XPOIID /XPOIID $\left.{ }_{t-1}\right)+b_{3}$. TXPOI + $b_{4} \cdot$ TREN $_{t}+b_{5} \cdot$ PRXPOIID ${ }_{t-1}+U 2_{t}$

Tanda dan besaran parameter estimasi yang diharapkan:

$b_{1}, b_{4}>0 ; b_{2}, b_{3}<0 ; 0<b_{5}<1$

PRXPOIID $D_{t}$ Harga riil ekspor CPO Indonesia ke India tahun $\mathrm{t}$ (USD/ton)

XPOIIDt : Rasio Ekspor CPO XPOIIDt-1 Indonesia ke India tahun $\mathrm{t}$ dan $\mathrm{t}-1$

TXPOIt : Pajak Ekspor CPO Indonesia tahun $\mathrm{t}$ (\%)

PRXPOIID $\mathrm{t}_{-1}$ : Harga riil ekspor CPO Indonesia ke India tahun $\mathrm{t}-1$ (USD/ton)

$\mathrm{U} 2 \mathrm{t}$

$$
\begin{aligned}
& \text { : Variabel } \\
& \text { pengganggu }
\end{aligned}
$$

Harga CPO Domestik

$\mathrm{PRPOD}_{\mathrm{t}}=\mathrm{c}_{0}+\mathrm{c}_{1} \cdot \mathrm{SPOD}+\mathrm{c}_{2}$. (DPOD $\mathrm{DPOD}_{t-1}+\mathrm{c}_{3} \cdot \mathrm{PRXPOIID}_{+}+\mathrm{c}_{4} \cdot$ TREN $_{t}+$ $\mathrm{C}_{5} \cdot \mathrm{PRPOD}_{\mathrm{t}-1}+\mathrm{U}_{\mathrm{t}}$
Tanda dan besaran parameter estimasi yang diharapkan:

$\mathrm{c}_{1}<0 ; \mathrm{C}_{2}, \mathrm{C}_{3}, \mathrm{C}_{4}>0 ; 0<\mathrm{C}_{5}<1$

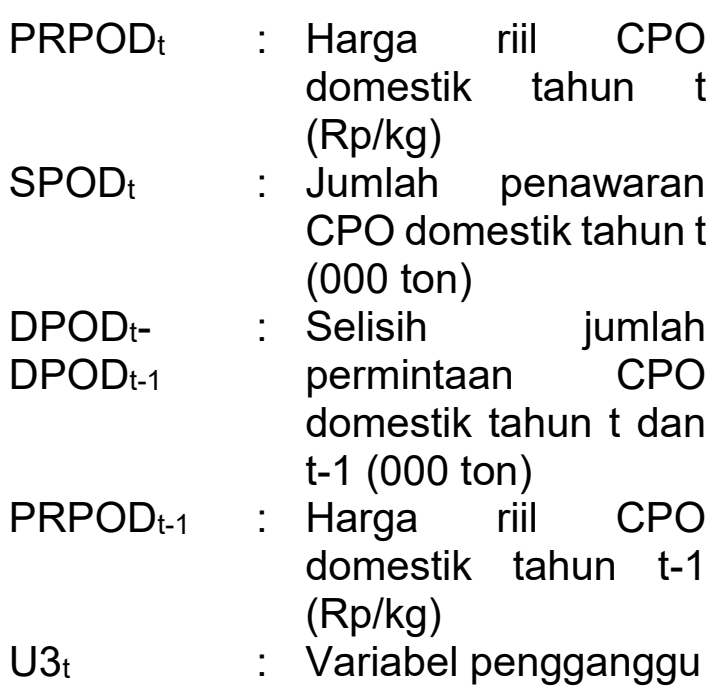

\section{Permintaan CPO oleh Industri}

\section{Minyak Goreng Sawit}

DPOIMG $_{\mathrm{t}}=\mathrm{d}_{0}+\mathrm{d}_{1} \cdot$ PRPOD $_{t}+$

$d_{2} \cdot P_{R M G D}+d_{3} \cdot\left(\right.$ WRIN - WRIN $\left._{t-1}\right)$

$+d_{4} \cdot B_{R R R}+d_{5} \cdot$ KAPQIMG +

$d_{6} \cdot D_{P O I M G}+U 4$

Tanda dan besaran parameter estimasi yang diharapkan:

$d_{2}, d_{5}>0 ; d_{1}, d_{3}, d_{4}<0 ; 0<d_{6}<1$

DPOIMG $_{t} \quad$ : Permintaan CPO oleh industri minyak goreng tahun $\mathrm{t}(000$ ton)

PRMGDt : Harga riil minyak goreng sawit domestik tahun $\mathrm{t}$ $(\mathrm{Rp} / \mathrm{kg})$

WRIN t $^{-} \quad$ : Selisih Upah riil pada

WRIN $\mathrm{t}_{\mathrm{t}}$ sektor industri tahun $\mathrm{t}$ dan $\mathrm{t}-1$ (Rp ribu /tahun)

$\mathrm{BIRR}_{\mathrm{t}}$ : Suku bunga riil $\mathrm{BI}$ tahun $\mathrm{t}(\%)$ 


$$
\begin{aligned}
& \text { KAPQIMG }{ }_{t} \text { : Kapasitas Produksi } \\
& \text { Industri Minyak } \\
& \text { Goreng Sawit } \\
& \text { tahun t (000 Ton) } \\
& \text { DPOIMG } \mathrm{t}_{-1} \text { : Permintaan CPO oleh } \\
& \text { industri minyak } \\
& \text { goreng tahun } \mathrm{t}-1 \text { (000 } \\
& \text { ton) } \\
& \mathrm{U} 4_{\mathrm{t}} \quad \text { : Variabel pengganggu }
\end{aligned}
$$

Permintaan CPO oleh Industri

\section{Margarin}

DPOIMR $_{\mathrm{t}}=\mathrm{e}_{0}+\mathrm{e}_{1} \cdot \mathrm{PRPOD}_{\mathrm{t}-1}+$

$e_{2} \cdot$ PRMRD $_{t}+e_{3} \cdot\left(\right.$ WRIN $_{t}-$ WRIN $\left._{t-1}\right)$

$+e_{4} \cdot$ BIRR $_{t-1}+e_{5} \cdot$ KAPQIMR $_{t}+$

$\mathrm{e}_{6}$. DPOIMR $\mathrm{t}_{\mathrm{t}-1}+\mathrm{U} 5_{\mathrm{t}}$

Tanda dan besaran parameter estimasi yang diharapkan:

$e_{2}, e_{5}>0 ; e_{1}, e_{3}, e_{4}<0 ; 0<e_{6}<1$

DPOIMR $_{t}$ : Permintaan CPO oleh industri margarine tahun $\mathrm{t}$ (000 ton)

PRPODt-1 : Harga riil CPO domestik tahun $\mathrm{t}-1$ (Rp/kg)

PRMRD $D_{t}$ : Harga riil margarine domestik tahun $\mathrm{t}$ (Rp/kg)

BIRRt-1 : Suku bunga riil BI tahun $\mathrm{t}-1$ (\%)

KAPQIMR $_{\mathrm{t}}$ : Kapasitas Produksi Industri Margarine tahun $\mathrm{t}$ (000 Ton)

DPOIMR $_{\mathrm{t}-1}$ : Permintaan CPO oleh industri margarine tahun $\mathrm{t}-1$ (000 ton)

U5t : Variabel pengganggu

Permintaan CPO oleh Industri Sabun

DPOISB $_{t}=f_{0}+f_{1}$. PRPOD ${ }_{t-1}+$ $f_{2} \cdot$ PRSBD $_{t-1}+f_{3} \cdot$ BIRR $_{t}+f_{4} \cdot$ KAPQISB $_{t}$

$+f_{5}$. DPOISB $B_{t-1}+U 6_{t}$

Tanda dan besaran parameter estimasi yang diharapkan: $f_{2}, f_{4}>0 ; f_{1}, f_{3}<0 ; 0<f_{5}<1$

DPOISB $_{t} \quad$ : Permintaan CPO oleh industri sabun tahun $\mathrm{t}$ (000 ton)

PRSBD $_{\mathrm{t}-1}$ : Harga riil sabun domestik tahun $\mathrm{t}-1$ (Rp/buah)

KAPQISB $_{t}$ : Kapasitas Produksi Industri Sabun tahun t (000 Ton)

DPOISB $_{\mathrm{t}-1}$ : Permintaan CPO oleh industri sabun tahun $\mathrm{t}$ 1 (000 ton)

U6t $\quad$ : Variabel pengganggu

\section{Total Permintaan CPO di Indonesia}

$\mathrm{DPOD}_{\mathrm{t}}=\mathrm{DPOIMG}_{t}+\mathrm{DPOIMR}_{\mathrm{t}}+$ $\mathrm{DPOISB}_{t}+\mathrm{DPOIL}_{t}$

DPODt $_{\mathrm{t}}$ : Total permintaan CPO di Indonesia tahun $\mathrm{t}(000$ ton)

DPOILt : Permintaan CPO oleh industri lain tahun $\mathrm{t}(000$ ton)

\section{Daya Saing CPO Indonesia dan}

\section{Malaysia}

Indikator daya saing yang digunakan dalam penelitian adalah Revealed Comparative Advantage $(R C A)$. Nilai indeks RCA diatas satu menunjukkan kondisi adanya keunggulan komparatif dalam mengekspor CPO, dan jika nilainya dibawah satu menunjukkan kondisi tidak memiliki keunggulan komparatif dalam mengekspor CPO. Daya saing CPO Indonesia dan Malaysia sebagai persamaan identitas: 


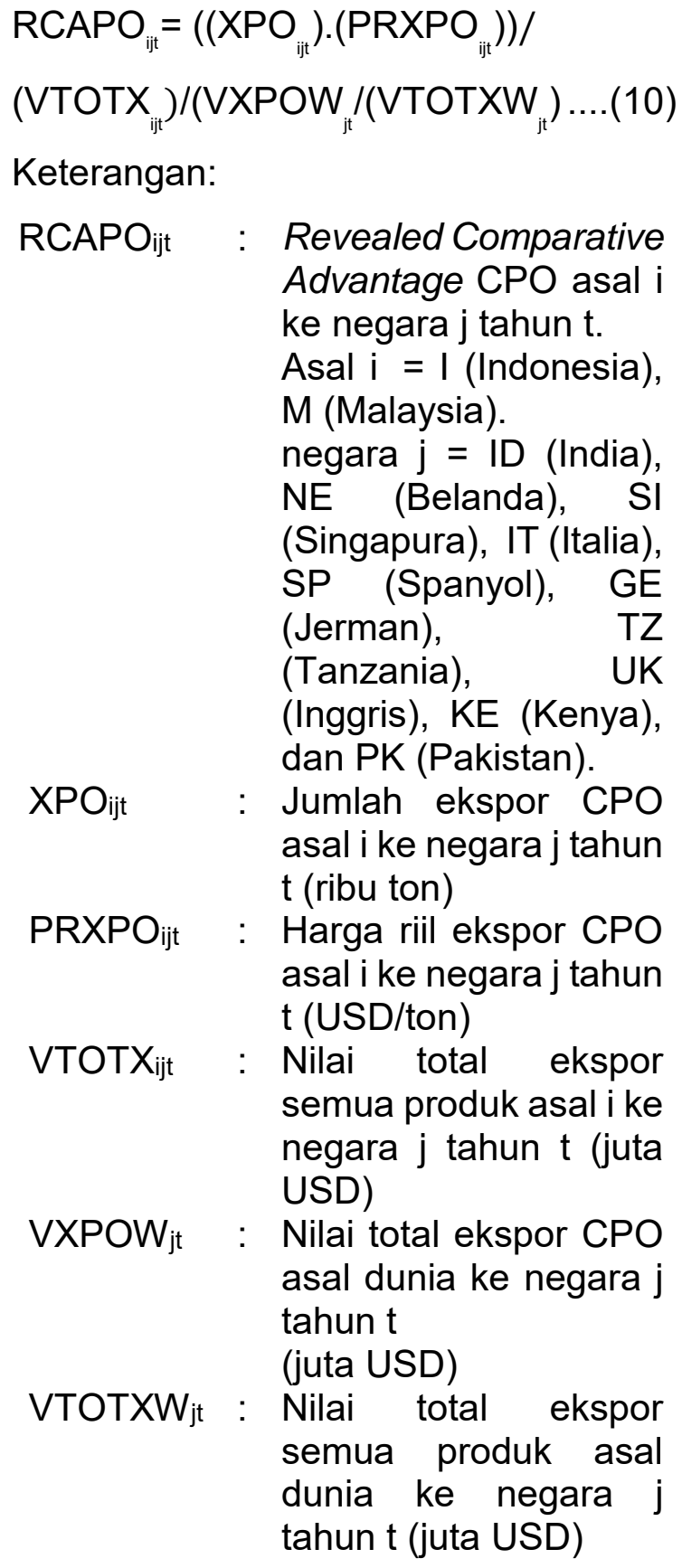

Daya Saing Minyak Goreng Sawit Indonesia

RCAMGIW $_{\mathrm{t}}=\left(\left(\mathrm{XMGIW}_{\mathrm{t}}\right) \cdot(\mathrm{PRXMGI})\right) /$

$\left(\right.$ VTOTXIW $\left._{t}\right) /\left(\right.$ VXMGW $_{+} /\left(\right.$VTOTXW $\left._{t}\right)$

Keterangan:

RCAMGIW $_{\mathrm{t}}$ : Revealed Comparative Advantage Minyak goreng sawit asal
Indonesia ke pasar dunia tahun $\mathrm{t}$

XMGIW $_{\mathrm{t}}$ : Jumlah ekspor minyak goreng sawit asal Indonesia ke pasar dunia tahun $\mathrm{t}$ (ribu ton)

PRXMGIt : Harga riil ekspor minyak goreng sawit Indonesia tahun $t$ (USD/ton)

VTOTXIW ${ }_{t}$ : Nilai total ekspor semua produk asal Indonesia ke pasar dunia tahun $t$ (juta USD)

VXMGW ${ }_{t}$ : Nilai total ekspor minyak goreng sawit di dunia tahun $t$ (juta USD)

VTOTXW $\mathrm{t}_{\mathrm{t}}$ : Nilai total ekspor semua produk di dunia tahun t (juta USD)

\section{Daya Saing Margarin Indonesia}

RCAMRIW $_{\mathrm{t}}=\left(\left(\mathrm{XMRIW}_{\mathrm{t}}\right) \cdot(\mathrm{PRXMRI})\right) /$

$\left(\right.$ VTOTXIW $\left._{\mathrm{t}}\right) /\left(\mathrm{VXMRW}_{\mathrm{t}} /\left(\right.\right.$ VTOTXW $\left._{\mathrm{t}}\right)$

Keterangan:

RCAMRIW $_{\mathrm{t}}$ : Revealed Comparative Advantage Margarin asal Indonesia ke pasar dunia tahun $\mathrm{t}$

XMRIW $_{t}$ : Jumlah ekspor margarin asal Indonesia ke pasar dunia tahun $\mathrm{t}$ (ribu ton)

PRXMRIt : Harga riil ekspor margarin Indonesia tahun $\mathrm{t}$ (USD/ton)

VXMRW $_{\mathrm{t}}$ : Nilai total ekspor margarin di dunia tahun $\mathrm{t}$ (juta USD) 


\section{Daya Saing Sabun Indonesia}

RCASBIW $_{\mathrm{t}}=\left(\left(\mathrm{XSBIW}_{\mathrm{t}}\right) \cdot\left(\mathrm{PRXSBI}_{\mathrm{t}}\right)\right) /$

$\left(\right.$ VTOTXIW $\left._{\mathrm{t}}\right) /\left(\right.$ VXSBW $_{\mathrm{t}} /\left(\right.$ VTOTXW $\left._{\mathrm{t}}\right)$

Keterangan:

\begin{tabular}{|c|c|}
\hline RCASBIW $_{\mathrm{t}}$ & $\begin{array}{l}\text { Revealed Comparative } \\
\text { Advantage sabun asal } \\
\text { Indonesia ke pasar } \\
\text { dunia tahun t }\end{array}$ \\
\hline $\mathrm{XSBIW}_{\mathrm{t}}$ & $\begin{array}{l}\text { Jumlah ekspor sabun } \\
\text { asal Indonesia ke pasar } \\
\text { dunia tahun t (ribu ton) }\end{array}$ \\
\hline PRXSBIt & $\begin{array}{l}\text { : Harga riil ekspor sabun } \\
\text { Indonesia tahun } \\
\text { (USD/ton) }\end{array}$ \\
\hline $\mathrm{VXSBW}_{\mathrm{t}}$ & $\begin{array}{l}\text { : Nilai total ekspor sabun } \\
\text { di dunia tahun t (juta }\end{array}$ \\
\hline
\end{tabular}

Penerimaan Devisa Ekspor CPO Indonesia

$\mathrm{RXPOIW}_{\mathrm{t}}=\sum_{\mathrm{j}=1}^{\mathrm{n}=10}\left(\mathrm{XPOI}_{\mathrm{jt}} \cdot \mathrm{PRXPOI_{jt }}\right.$. $\left.E R I_{t}\right)+\left(X P^{\prime} O W_{t} \cdot P R P O W_{t} . E R I_{t}\right)$

\begin{tabular}{|c|c|}
\hline $\mathrm{RXPOIW}_{\mathrm{t}}$ & $\begin{array}{l}\text { Penerimaan devisa } \\
\text { ekspor CPO Indonesia } \\
\text { tahun t (Rp) }\end{array}$ \\
\hline $\mathrm{XPOl}_{\mathrm{jt}}$ & $\begin{array}{l}\text { : Jumlah ekspor CPO } \\
\text { Indonesia ke negara j } \\
\text { tahun t (ribu ton) } \\
\text { negara j }=1 \text { India, } 2 \\
\text { Belanda, } 3 \text { Singapura, } \\
4 \text { Italia, } 5 \text { Spanyol, } 6 \\
\text { Jerman, } 7 \text { Tanzania, } 8 \\
\text { Inggris, } 9 \text { Kenya, dan } 10 \\
\text { Pakistan. }\end{array}$ \\
\hline $\mathrm{PRXPOl}_{\mathrm{jt}}$ & $\begin{array}{l}\text { : Harga riil ekspor CPO } \\
\text { Indonesia ke negara j } \\
\text { tahun } \mathrm{j} \text { (USD/ton) }\end{array}$ \\
\hline ERIt & $\begin{array}{l}\text { Nilai tukar riil Rupiah } \\
\text { terhadap US dollar } \\
\text { tahun } t(\mathrm{Rp} / \mathrm{USD})\end{array}$ \\
\hline
\end{tabular}

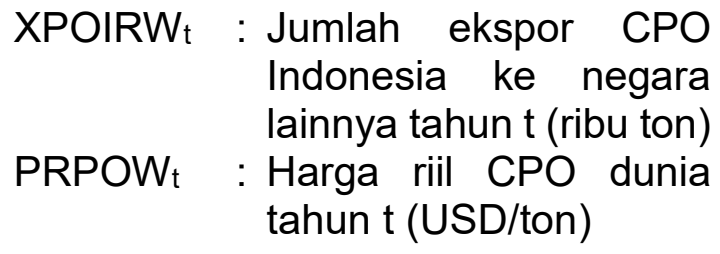

Penerimaan Devisa Ekspor Minyak Goreng Sawit

$R X M G I W_{t}=X M G I W_{t} \cdot P R X M G I_{t} \cdot E R I_{t}$

$$
\begin{aligned}
\text { RXMGIW }_{\mathrm{t}}: & \text { Penerimaan devisa } \\
& \text { ekspor minyak goreng } \\
& \text { sawit Indonesia tahun t } \\
& (\mathrm{Rp})
\end{aligned}
$$

\section{Penerimaan Devisa Ekspor Margarin}

$R_{X M R I W}=X_{t} M R I W_{t} \cdot P R X M R I_{t} \cdot E R I_{t}$

$$
\begin{array}{ll}
\mathrm{RXMRIW}_{\mathrm{t}}: & \begin{array}{l}
\text { Penerimaan devisa } \\
\text { ekspor margarin } \\
\text { Indonesia tahun } \mathrm{t}(\mathrm{Rp})
\end{array}
\end{array}
$$

\section{Penerimaan Devisa Ekspor Sabun}

$\mathrm{RXSBIW}_{\mathrm{t}}=\mathrm{XSBIW}_{\mathrm{t}} \cdot \mathrm{PRXSBI}_{\mathrm{t}} \cdot \mathrm{ERI}_{\mathrm{t}}$

$$
\begin{aligned}
\text { RXSBIW }_{\mathrm{t}}: & \begin{array}{l}
\text { Penerimaan devisa } \\
\text { ekspor sabun Indonesia } \\
\text { tahun } \mathrm{t}(\mathrm{Rp})
\end{array}
\end{aligned}
$$

Parameter persamaan dalam model diestimasi dengan metode 2SLS (Two Stage Least Squares). Adapun persamaan yang diestimasi menggunakan metode 2SLS adalah persamaan struktural yaitu: 1, 4, 5, 6, 7, 8, sedangkan persamaan lainnya merupakan persamaan identitas yang diperoleh hasilnya dari validasi model. Selanjutnya model divalidasi menggunakan metode Newton dan 
dilakukan analisis dampak perubahan faktor eksternal dan kebijakan domestik terhadap: (1) daya saing ekspor CPO Indonesia-Malaysia dan daya saing ekspor minyak goreng sawit, margarin dan sabun Indonesia, dan (2) penerimaan devisa ekspor CPO, minyak goreng sawit, margarin dan sabun Indonesia periode 2015-2017. Skenario simulasi historis (historical simulation) periode 2015-2017 yang dianalisis adalah: (1) peningkatan pajak impor CPO India sebesar 100\%, peningkatan kapasitas produksi industri minyak goreng sawit, margarin dan sabun di Indonesia masing-masing sebesar $5 \%$, $10 \%$, dan $40 \%$, serta peningkatan permintaan CPO oleh industri lain sebesar $30 \%$, dan (3) kombinasi skenario 1 dan skenario 2 .

Jenis data yang digunakan dalam penelitian adalah data sekunder dengan rentang waktu (time series) dari tahun 1990 sampai dengan tahun 2017. Sumber data dalam penelitian ini diperoleh dari beberapa instansi yaitu: Badan Pusat Statistik (BPS, 2018), Direktorat Jenderal PerkebunanKementerian Pertanian, UN Comtrade, Capricorn Indonesia Consult (CIC) dan Oil World. Pengolahan data dilakukan dengan program komputer yaitu: SAS/ETS for Windows 9.4.
HASIL DAN PEMBAHASAN

Faktor-Faktor yang Memengaruhi Impor CPO India dari Dunia

Hasil estimasi parameter persamaan 1 impor CPO India ditunjukkan pada Tabel 1. Impor CPO India pada tahun $t$ (MPOIDW $\mathrm{M}_{\mathrm{t}}$ dipengaruhi secara signifikan oleh variabel harga riil minyak mentah dunia tahun $\mathrm{t}-1$, harga riil minyak kedele dunia tahun $\mathrm{t}-1$, tren waktu, dan impor CPO India tahun t-1 (LMPONEW). Pengaruh LMPOIDW yang signifikan menunjukkan bahwa ada tenggang waktu yang relatif lambat bagi MPOIDW menyesuaikan diri dalam merespon perubahan ekonomi yang terjadi.

Impor CPO India pada tahun $t$ $\left(M\right.$ POIDW $\left.{ }_{t}\right)$ tidak dipengaruhi secara signifikan oleh harga riil impor CPO India tahun t-1. Hal ini sejalan hasil Nurmalita \& Bowo (2019) bahwa harga minyak kelapa sawit internasional berpengaruh positif tetapi tidak signifikan terhadap volume ekspor minyak kelapa sawit Indonesia ke India.

Angshu Mallick, deputy CEO, Adani Wilmar menyatakan bahwa harga minyak mentah yang lebih tinggi dapat memengaruhi harga bahan bakar nabati (biofuel) dan ini pada gilirannya juga dapat memengaruhi harga minyak 
nabati. India mengimpor hampir $70 \%$ dari konsumsi tahunan minyak nabati yang mencapai 23,5 juta ton. Minyak kelapa sawit adalah minyak nabati yang paling banyak dikonsumsi di India dengan pangsa $40 \%$, diikuti oleh kedele dan minyak mustard (Sally, 2019).
Selain itu, menurut World Bank, nilai elastisitas dari harga minyak mentah ke harga komoditas pertanian naik dari 0,22 untuk periode sebelum 2005 menjadi 0,28 hingga 2009 (Mukherjee \& Sovacool, 2014).

\section{Tabel 1. Hasil Estimasi Persamaan Impor CPO India}

\begin{tabular}{|c|c|c|c|c|c|}
\hline \multirow{2}{*}{ Variabel } & \multirow{2}{*}{$\begin{array}{l}\text { Estimasi } \\
\text { Parameter }\end{array}$} & \multicolumn{2}{|c|}{ Elastisitas } & \multirow{2}{*}{ Prob $>|\mathrm{T}|$} & \multirow{2}{*}{$\begin{array}{c}\text { Label } \\
\text { Variabel }\end{array}$} \\
\hline & & SR & LR & & \\
\hline Intercept & -1486.3100 & & & 0.0278 & \\
\hline LPMPOIDW & -0.3529 & -0.1281 & -0.2431 & 0.2864 & $\begin{array}{l}\text { Harga riil impor CPO India } \\
\text { tahun } \mathrm{t}-1 \text { (US.\$/ton) }\end{array}$ \\
\hline LPRCOW & 13.3772 & 0.2496 & 0.4736 & $0.0981^{* * *}$ & $\begin{array}{l}\text { Harga riil minyak mentah dunia } \\
\text { tahun t-1 (US.\$/barrel) }\end{array}$ \\
\hline LPRSOW & 0.7527 & 0.2303 & 0.4370 & $0.1973^{*}$ & $\begin{array}{l}\text { Harga riil minyak kedele dunia } \\
\text { tahun t-1 (US.\$/ton) }\end{array}$ \\
\hline DNBMPOID & 260.9236 & - & - & 0.3255 & $\begin{array}{l}\text { Dummy Hambatan Non Tarif } \\
\text { Impor CPO oleh India } \\
(1=\text { ada, } 0=\text { tidak ada })\end{array}$ \\
\hline TREN & 136.2787 & - & - & $0.0082^{* * * *}$ & Tren Waktu \\
\hline LMPOIDW & 0.4730 & - & - & $0.0059^{* * * *}$ & $\begin{array}{l}\text { Impor CPO India tahun } \mathrm{t}-1 \text { (000 } \\
\text { ton) }\end{array}$ \\
\hline R-squared & 0.9483 & Prob $>|F|$ & $<0.0001$ & Durbin-h stat & -1.7470 \\
\hline
\end{tabular}

Keterangan: $\mathrm{SR}=$ jangka pendek, $\mathrm{LR}=$ jangka panjang

* = signifikan pada taraf $\alpha=25 \%,{ }^{* *}=$ signifikan pada taraf $\alpha=15 \%$

$* * *=$ signifikan pada taraf $\alpha=10 \%,{ }^{* * * *}=$ signifikan pada taraf $\alpha=5 \%$

Berdasarkan informasi tersebut dapat dijelaskan bahwa saat harga minyak mentah dunia meningkat, maka permintaan biofuel sebagai substitusi minyak mentah akan meningkat. Kenaikan permintaan biofuel termasuk biodiesel akan meningkatkan impor CPO India. Selanjutnya, jika harga minyak kedele dunia naik, ceteris paribus, maka India akan meningkatkan impor CPO sebagai substitusi minyak kedele. Menurut Ernawati et al. (2006), nilai elastisitas jangka pendek dari ekspor demand Indonesia ke India terhadap perubahan rasio harga minyak kedele dan minyak sawit sebesar 2,74. Hal ini menunjukkan bahwa di India minyak kedele merupakan substusi minyak sawit. Awad et al. (2007) menyatakan bahwa impor CPO di negara-negara middle east and north african (MENA) dipengaruhi oleh harga 
CPO, harga minyak substitusinya, pendapatan nasional dan faktor spesifik masing-masing negara.

India meningkatkan pajak impor CPO termasuk CPO yang berasal dari Indonesia dalam rangka memproteksi industri minyak kedele domestik dan petani kedelenya. Dengan adanya kenaikan pajak impor CPO, ceteris paribus, maka harga CPO yang diimpor menjadi lebih tinggi sedangkan harga minyak nabati lain termasuk minyak kedele adalah tertentu (given) sehingga impor CPO India dari dunia termasuk Indonesia mengalami penurunan. Ernawati et al. (2006), pengurangan tarif pajak impor CPO India menyebabkan volume ekspor CPO Indonesia ke India mengalami peningkatan.

Adapun menurut Negoro et al. (2020) tarif yang diberlakukan India terhadap CPO Indonesia memiliki hubungan yang elastis dibandingkan dengan harga CPO. Selain itu, studi ini menemukan bahwa perubahan tarif cenderung berpengaruh signifikan terhadap ekspor CPO Indonesia ke India dibandingkan harga CPO.

Menurut Destiarni et al. (2021) pengembangan pasar ekspor CPO Indonesia dilakukan sebagai langkah untuk mengantisipasi black campaign jangka panjang terkait perkebunan kelapa sawit dan penggunaan CPO. Jika Indonesia tidak memiliki pasar alternatif maka akan berdampak domino pada agribisnis CPO dalam negeri. Indonesia harus mencari alternatif pasar dan strategi untuk mengantisipasi black campaign dan trade wars yang terjadi di pasar utama CPO Indonesia. Salah satu inisiatif yang dapat diambil untuk mencari pasar alternatif adalah berdagang dengan negara-negara yang menjadi pasar non tradisional Indonesia yaitu: Pakistan, Mesir, Banglades, Kenya, Mozambique, Singapura, Ghana, United Republic of Tanzania, Morocco, Côte d'Ivoire dan Cameroon.

\section{Faktor-Faktor yang Memengaruhi Harga Ekspor CPO Indonesia ke India} Berdasarkan hasil estimasi parameter persamaan harga ekspor CPO Indonesia ke India (persamaan 4), diketahui bahwa harga ekspor CPO Indonesia ke India tahun t (PRXPOIIDt) dipengaruhi secara signifikan oleh variabel harga riil CPO dunia tahun $t$, rasio ekspor CPO Indonesia ke India tahun $\mathrm{t}$ dan $\mathrm{t}-1$, pajak ekspor CPO Indonesia tahun $\mathrm{t}$, dan harga riil ekspor CPO Indonesia ke India tahun t-1 (Tabel 2).

Nilai elastisitas harga ekspor CPO Indonesia ke India tahun $\mathrm{t}$ terhadap harga riil $\mathrm{CPO}$ dunia tahun $\mathrm{t}$ adalah 
unitary elastis dalam jangka pendek dan elastis dalam jangka panjang. Hal ini berarti dalam jangka panjang, jika harga CPO dunia menurun sebesar $1 \%$ (misalnya karena peningkatan pajak impor CPO India yang menurunkan impor CPO India maupun impor CPO dunia) maka harga ekspor CPO Indonesia ke India akan mengalami penurunan lebih besar dari $1 \%$.

Sementara nilai elastisitas harga ekspor CPO Indonesia ke India tahun t terhadap rasio ekspor CPO Indonesia ke India tahun $\mathrm{t}$ dan $\mathrm{t}-1$ maupun nilai elastisitas harga ekspor CPO Indonesia ke India tahun $t$ terhadap pajak ekspor CPO Indonesia tahun $t$ adalah inelastis dalam jangka pendek dan jangka panjang. Hal ini berarti dalam jangka pendek maupun jangka panjang, jika terjadi peningkatan rasio ekspor CPO Indonesia ke India tahun t dan t-1 atau peningkatan pajak ekspor CPO Indonesia tahun $\mathrm{t}$ sebesar $1 \%$ maka harga ekspor CPO Indonesia ke India akan mengalami penurunan lebih kecil dari $1 \%$.

Tabel 2. Hasil Estimasi Persamaan Harga Ekspor CPO Indonesia ke India

\begin{tabular}{|c|c|c|c|c|c|}
\hline \multirow{2}{*}{ Variabel } & \multirow{2}{*}{$\begin{array}{l}\text { Estimasi } \\
\text { Parameter }\end{array}$} & \multicolumn{2}{|c|}{ Elastisitas } & \multirow{2}{*}{ Prob $>|T|$} & \multirow{2}{*}{$\begin{array}{l}\text { Label } \\
\text { Variabel }\end{array}$} \\
\hline & & SR & LR & & \\
\hline Intercept & -75.5062 & & & 0.1359 & \\
\hline PRPOW & 0.8673 & 0.9912 & 1.1687 & $<0.0001^{* * * *}$ & Harga riil CPO dunia tahun $\mathrm{t}$ (US.\$/ton) \\
\hline RXPOIID & -0.2341 & -0.0015 & -0.0017 & $0.0870^{* * *}$ & $\begin{array}{l}\text { Rasio Ekspor CPO Indonesia ke India } \\
\text { tahun t dan t-1 }\end{array}$ \\
\hline TXPOI & -1.0858 & -0.0210 & -0.0247 & $0.2160^{*}$ & Pajak Ekspor CPO Indonesia tahun t (\%) \\
\hline TREN & 0.1077 & - & - & 0.4843 & Tren Waktu \\
\hline LPXPOIID & 0.1519 & - & - & $0.0948^{* * *}$ & $\begin{array}{l}\text { Harga riil ekspor CPO } \\
\text { Indonesia ke India tahun t-1 (US.\$/ton) }\end{array}$ \\
\hline
\end{tabular}

Keterangan: $\mathrm{SR}=$ jangka pendek, $\mathrm{LR}=$ jangka panjang

* = signifikan pada taraf $\alpha=25 \%,{ }^{* *}=$ signifikan pada taraf $\alpha=15 \%$

$* * *=$ signifikan pada taraf $\alpha=10 \%,{ }^{* * *}=$ signifikan pada taraf $\alpha=5 \%$

Faktor-Faktor yang Memengaruhi Harga CPO domestik, Permintaan CPO oleh Industri Minyak Goreng Sawit, Margarin dan Sabun di Indonesia

Hasil estimasi parameter persamaan harga CPO domestik tahun t ditunjukkan pada Tabel 3 (persamaan 5). Diketahui bahwa harga riil CPO domestik tahun $t\left(P R P O D_{t}\right)$ dipengaruhi secara signifikan oleh variabel jumlah penawaran CPO domestik tahun $t$, harga riil ekspor CPO Indonesia ke India tahun $\mathrm{t}$, tren waktu, dan harga riil CPO 
domestik tahun t-1 (PRPOD $t-1)$. Harga CPO domestik tahun $t$ dipengaruhi secara signifikan oleh variabel lagnya (PRPOD $_{\mathrm{t}-1)}$ menunjukkan bahwa ada tenggang waktu yang relatif lambat bagi PRPODt untuk menyesuaikan diri dalam merespon perubahan ekonomi yang terjadi. Nilai estimasi parameter harga riil ekspor CPO Indonesia ke India tahun t sebesar 2,3572 artinya jika harga riil ekspor CPO Indonesia ke India tahun $t$ meningkat sebesar USD 1000 per ton maka harga CPO domestik tahun $t$ akan naik sebesar Rp 2.357.200,00 per ton.

\section{Tabel 3. Hasil Estimasi Persamaan Harga CPO Domestik}

\begin{tabular}{|c|c|c|c|c|c|}
\hline \multirow{2}{*}{ Variabel } & \multirow{2}{*}{$\begin{array}{l}\text { Estimasi } \\
\text { Parameter }\end{array}$} & \multicolumn{2}{|c|}{ Elastisitas } & \multirow{2}{*}{ Prob $>|T|$} & \multirow{2}{*}{$\begin{array}{l}\text { Label } \\
\text { Variabel }\end{array}$} \\
\hline & & SR & LR & & \\
\hline Intercept & 3123.9660 & & & 0.0289 & \\
\hline SPOD & -0.1193 & -0.2064 & -0.2996 & $0.1912^{*}$ & $\begin{array}{l}\text { Jumlah penawaran CPO } \\
\text { domestik tahun } \mathrm{t}(000 \text { ton) }\end{array}$ \\
\hline DDPOD & 0.3756 & 0.0138 & 0.0200 & 0.2673 & $\begin{array}{l}\text { Selisih jumlah permintaan CPO } \\
\text { domestik tahun t dan } \mathrm{t}-1 \text { (000 } \\
\text { ton) }\end{array}$ \\
\hline PRXPOIID & 2.3572 & 0.1934 & 0.2806 & $0.0831^{* * *}$ & $\begin{array}{l}\text { Harga riil ekspor CPO } \\
\text { Indonesia } \\
\text { ke India tahun t (US.\$/ton) }\end{array}$ \\
\hline TREN & 145.3156 & - & - & $0.2102^{*}$ & Tren Waktu \\
\hline LPRPOD & 0.3109 & - & - & $0.1259^{* *}$ & $\begin{array}{l}\text { Harga riil CPO domestik } \\
\text { tahun } \mathrm{t}-1(\mathrm{Rp} / \mathrm{kg})\end{array}$ \\
\hline R-squared & 0.3649 & Prob $>|F|$ & 0.0705 & Durbin-h stat & Tidak Terdefinisikan \\
\hline
\end{tabular}

Keterangan: $\mathrm{SR}$ = jangka pendek, $\mathrm{LR}$ = jangka panjang

* = signifikan pada taraf $\alpha=25 \%,{ }^{* *}=$ signifikan pada taraf $\alpha=15 \%$

*** $=$ signifikan pada taraf $\alpha=10 \%,{ }^{* * *}=$ signifikan pada taraf $\alpha=5 \%$

Berdasarkan hasil estimasi pada Tabel 4, diketahui bahwa permintaan CPO oleh industri minyak goreng sawit tahun $\mathrm{t}$ (Persamaan 6) dipengaruhi secara signifikan oleh variabel kapasitas produksi industri minyak goreng sawit tahun $\mathrm{t}$ dan permintaan CPO oleh industri minyak goreng sawit tahun $\mathrm{t}-1$ (DPOIMG -1 ). DPOIMG $\mathrm{t}_{\mathrm{t}}$ dipengaruhi secara signifikan oleh variabel lagnya (DPOIMG $\mathrm{t}_{-1}$ ) menunjukkan bahwa ada tenggang waktu yang relatif lambat bagi DPOIMG untuk menyesuaikan diri dalam merespon perubahan ekonomi yang terjadi.

Nilai elastisitas permintaan CPO oleh industri minyak goreng sawit terhadap kapasitas produksi industri minyak goreng sawit adalah inelastis dalam jangka pendek $(0,13)$ dan unitary elastis dalam jangka panjang $(0,99)$. Kemudian, diketahui bahwa nilai ratarata permintaan CPO oleh industri minyak goreng sawit dan kapasitas produksi industri minyak goreng sawit periode 2015-2017 masing-masing 
adalah $4.714,28$ ribu ton dan $19.054,30$

ribu ton. Hal ini berarti dengan basis nilai rata-ratanya periode 2015-2017, jika ada peningkatan kapasitas produksi industri minyak goreng sawit sebesar $1 \% \quad(190,54$ ribu ton) akan meningkatkan permintaan CPO oleh industri minyak goreng sawit sebesar $0,13 \%$ (6,13 ribu ton) dalam jangka pendek dan sebesar $1 \%(47,14$ ribu ton) dalam jangka panjang.

\section{Tabel 4. Hasil Estimasi Persamaan Permintaan CPO oleh Industri Minyak Goreng Sawit}

\begin{tabular}{|c|c|c|c|c|c|}
\hline \multirow{2}{*}{ Variabel } & \multirow{2}{*}{$\begin{array}{l}\text { Estimasi } \\
\text { Parameter }\end{array}$} & \multicolumn{2}{|c|}{ Elastisitas } & \multirow{2}{*}{ Prob $>|T|$} & \multirow{2}{*}{$\begin{array}{c}\text { Label } \\
\text { Variabel }\end{array}$} \\
\hline & & SR & LR & & \\
\hline Intercept & 85.0451 & & & 0.4709 & \\
\hline PRPOD & -0.0082 & -0.0231 & -0.1721 & 0.4622 & $\begin{array}{l}\text { Harga riil CPO domestik } \\
\text { tahun } \mathrm{t}(\mathrm{Rp} / \mathrm{kg})\end{array}$ \\
\hline PRMGD & 0.0102 & 0.0511 & 0.3802 & 0.4572 & $\begin{array}{l}\text { Harga riil minyak goreng sawit } \\
\text { domestik tahun } \mathrm{t}(\mathrm{Rp} / \mathrm{kg})\end{array}$ \\
\hline DWRIN & -0.0106 & -0.0035 & -0.0261 & 0.4543 & $\begin{array}{l}\text { Selisih Upah riil pada sektor } \\
\text { industri tahun t dan } \mathrm{t}-1 \\
\text { (Rp ribu /tahun) }\end{array}$ \\
\hline BIRR & -7.9303 & -0.0098 & -0.0729 & 0.3827 & Suku bunga riil $\mathrm{BI}$ tahun $\mathrm{t}(\%)$ \\
\hline KAPQIMG & 0.0358 & 0.1331 & 0.9906 & $0.1662^{*}$ & $\begin{array}{l}\text { Kapasitas Produksi Industri } \\
\text { Minyak Goreng Sawit } \\
\text { tahun t (000 Ton) }\end{array}$ \\
\hline LDPOIMG & 0.8656 & - & - & $<0.0001^{* * * *}$ & $\begin{array}{l}\text { Permintaan CPO oleh industri } \\
\text { minyak goreng tahun } \mathrm{t}-1 \text { ( } 000 \\
\text { ton) }\end{array}$ \\
\hline R-squared & 0.9080 & Prob $>|F|$ & $<0.0001$ & Durbin-h stat & -1.2341 \\
\hline
\end{tabular}

Keterangan: $\mathrm{SR}=$ jangka pendek, $\mathrm{LR}=$ jangka panjang

* = signifikan pada taraf $\alpha=25 \%,{ }^{*}=$ signifikan pada taraf $\alpha=15 \%$

*** $=$ signifikan pada taraf $\alpha=10 \%,{ }^{* * * *}=$ signifikan pada taraf $\alpha=5 \%$ 
Tabel 5. Hasil Estimasi Persamaan Permintaan CPO oleh Industri Margarin

\begin{tabular}{|c|c|c|c|c|c|}
\hline \multirow{2}{*}{ Variabel } & \multirow{2}{*}{$\begin{array}{l}\text { Estimasi } \\
\text { Parameter }\end{array}$} & \multicolumn{2}{|c|}{ Elastisitas } & \multirow{2}{*}{ Prob $>|\mathrm{T}|$} & \multirow{2}{*}{$\begin{array}{l}\text { Label } \\
\text { Variabel }\end{array}$} \\
\hline & & SR & LR & & \\
\hline Intercept & 1.1051 & & & 0.4860 & \\
\hline LPRPOD & -0.0090 & -0.3542 & -0.8054 & $0.0083^{* * \star *}$ & $\begin{array}{l}\text { Harga riil CPO domestik } \\
\text { tahun t-1 (Rp/kg) }\end{array}$ \\
\hline PRMRD & 0.0028 & 0.3830 & 0.8708 & $0.0060^{* * * *}$ & $\begin{array}{l}\text { Harga riil margarine domestik } \\
\text { tahun } \mathrm{t}(\mathrm{Rp} / \mathrm{kg})\end{array}$ \\
\hline DWRIN & -0.0015 & -0.0070 & -0.0159 & 0.3320 & $\begin{array}{l}\text { Selisih Upah riil pada sektor } \\
\text { industri tahun } \mathrm{t} \text { dan } \mathrm{t}-1 \\
\text { (Rp ribu /tahun) }\end{array}$ \\
\hline LBIRR & -0.1025 & -0.0020 & -0.0045 & 0.4642 & Suku bunga riil BI tahun $\mathrm{t}-1$ (\%) \\
\hline KAPQIMR & 0.1716 & 0.4482 & 1.0191 & $0.0060^{* * * *}$ & $\begin{array}{l}\text { Kapasitas Produksi Industri } \\
\text { Margarine tahun t (000 Ton) }\end{array}$ \\
\hline LDPOIMR & 0.5602 & - & - & $0.0006^{* * * *}$ & $\begin{array}{l}\text { Permintaan CPO oleh industri } \\
\text { margarine tahun } \mathrm{t}-1 \text { (000 ton) }\end{array}$ \\
\hline R-squared & 0.9682 & Prob $>|F|$ & $<0.0001$ & Durbin-h stat & -2.0562 \\
\hline
\end{tabular}

Keterangan: $\mathrm{SR}=$ jangka pendek, $\mathrm{LR}=$ jangka panjang

* = signifikan pada taraf $\alpha=25 \%,{ }^{* *}=$ signifikan pada taraf $\alpha=15 \%$

$* * *=$ signifikan pada taraf $\alpha=10 \%,{ }^{* * *}=$ signifikan pada taraf $\alpha=5 \%$

Hasil estimasi parameter pada

Permintaan CPO oleh industri persamaan permintaan CPO oleh industri margarin tahun $\mathrm{t}$ (Persamaan 7) menunjukkan permintaan CPO oleh industri margarin tahun $t$ dipengaruhi secara signifikan oleh variabel harga riil $\mathrm{CPO}$ domestik tahun $\mathrm{t}-1$, harga riil margarin domestik tahun $t$, kapasitas produksi industri margarin tahun $t$ dan permintaan CPO oleh industri margarin tahun t-1 (Tabel 5). Nilai elastisitas permintaan CPO oleh industri margarin terhadap kapasitas produksi industri margarin adalah inelastis dalam jangka pendek $(0,45)$ dan elastis dalam jangka panjang $(1,02)$. sabun (Persamaan 8) tahun $t$ dipengaruhi secara nyata oleh variabel harga riil CPO domestik tahun $\mathrm{t}-1$, kapasitas produksi industri sabun tahun $\mathrm{t}$ dan permintaan CPO oleh industri sabun tahun t-1 (DPOISB $\mathrm{t}_{-1}$ ) (Tabel 6). Nilai elastisitas permintaan CPO oleh industri sabun terhadap harga riil CPO domestik tahun $\mathrm{t}-1$ dan nilai elastisitas permintaan CPO oleh industri sabun terhadap kapasitas produksi industri sabun adalah inelastis dalam jangka pendek namun elastis dalam jangka panjang. 
Tabel 6. Hasil Estimasi Persamaan Permintaan CPO oleh Industri Sabun

\begin{tabular}{|c|c|c|c|c|c|}
\hline \multirow{2}{*}{ Variabel } & \multirow{2}{*}{$\begin{array}{l}\text { Estimasi } \\
\text { Parameter }\end{array}$} & \multicolumn{2}{|c|}{ Elastisitas } & \multirow{2}{*}{ Prob $>|\mathrm{T}|$} & \multirow{2}{*}{$\begin{array}{c}\text { Label } \\
\text { Variabel }\end{array}$} \\
\hline & & SR & LR & & \\
\hline Intercept & 50.2515 & & & 0.1337 & \\
\hline LPRPOD & -0.0050 & -0.1252 & -1.2556 & $0.2159^{*}$ & $\begin{array}{l}\text { Harga riil CPO domestik } \\
\text { tahun t-1 (Rp/kg) }\end{array}$ \\
\hline LPRSBD & 0.0010 & 0.0100 & 0.1008 & 0.4714 & $\begin{array}{l}\text { Harga riil sabun domestik } \\
\text { tahun } \mathrm{t}-1 \text { (Rp/buah) }\end{array}$ \\
\hline BIRR & -0.9332 & -0.0104 & -0.1045 & 0.3158 & Suku bunga riil $\mathrm{Bl}$ tahun $\mathrm{t}(\%)$ \\
\hline KAPQISB & 0.0355 & 0.1135 & 1.1380 & $0.0326^{* * * *}$ & $\begin{array}{l}\text { Kapasitas Produksi Industri } \\
\text { Sabun tahun } \mathrm{t}(000 \text { Ton) }\end{array}$ \\
\hline LDPOISB & 0.9003 & - & - & $<0.0001^{* * * *}$ & $\begin{array}{l}\text { Permintaan CPO oleh industri } \\
\text { sabun tahun } \mathrm{t}-1 \text { (000 ton) }\end{array}$ \\
\hline R-squared & 0.9522 & Prob $>|F|$ & $<0.0001$ & Durbin-h stat & -1.3654 \\
\hline
\end{tabular}

Keterangan: $\mathrm{SR}=$ jangka pendek, $\mathrm{LR}=$ jangka panjang

* $\quad=$ signifikan pada taraf $\alpha=25 \%,{ }^{* *}=$ signifikan pada taraf $\alpha=15 \%$

${ }^{* * *}=$ signifikan pada taraf $\alpha=10 \%,{ }^{* * * *}=$ signifikan pada taraf $\alpha=5 \%$

Berdasarkan hasil estimasi persamaan permintaan CPO oleh industri minyak goreng sawit (Persamaan 6), margarin (Persamaan 7) dan sabun (Persamaan 8), diketahui bahwa permintaan CPO oleh industri hilir CPO dipengaruhi secara signifikan oleh kapasitas produksi industri hilir CPO. Kemudian, nilai elastisitas permintaan CPO oleh industri hilir CPO terhadap kapasitas produksi industri hilir CPO adalah elastis dalam jangka panjang. Hal ini menunjukkan dalam jangka panjang, kapasitas produksi industri hilir CPO merupakan instrumen yang sangat penting dalam rangka meningkatkan permintaan CPO di pasar domestik dan produksi produk turunan CPO, khususnya minyak goreng sawit, margarin dan sabun. Novindra (2011) dan Novindra et al. (2019) menyatakan bahwa pengembangan industri hilir CPO domestik akan meningkatkan permintaan CPO domestik, sehingga meningkatkan harga CPO yang diterima oleh produsen CPO.

Menurut GAPKI (2017), melalui kegiatan hilirisasi CPO dihasilkan produk-produk bernilai tambah lebih tinggi baik untuk tujuan ekspor maupun untuk pengganti produk yang diimpor selama ini seperti solar, avtur, premium, plastik, pelumas dan sebagainya. Menurut Rifai (2014) Indonesia baru mengembangkan 47 jenis produk turunan dengan kapasitas terpakai pabrik rata-rata 90\%. Agar Indonesia bisa mengalahkan Malaysia, maka kapasitas produksi pabrik harus ditingkatkan dengan memberikan 
kemudahan untuk berinvestasi pendirian pabrik dan investasi dalam riset dan pengembangan produk turunan sawit di Indonesia.

\section{Dampak Perubahan Pajak Impor CPO} India dan Kapasitas Produksi Industri Hilir CPO terhadap Daya Saing dan Penerimaan Devisa Ekspor Indonesia

Hasil validasi model periode 20152017 menunjukkan nilai U-Theil variabel endogen yaitu: impor CPO India dari Pasar Dunia sebesar 0,07; harga ekspor CPO Indonesia ke India sebesar 0,09; harga CPO domestik sebesar 0,13; serta permintaan CPO oleh industri minyak goreng sawit, margarin dan sabun masing-masing sebesar 0,06; 0,07; dan 0,05. Dengan demikian secara umum model yang dibangun mempunyai daya prediksi yang cukup valid dan baik digunakan untuk melakukan berbagai alternatif skenario simulasi (alternative simulation scenarios), termasuk simulasi dampak perubahan faktor eksternal dan kebijakan domestik terhadap daya saing ekspor CPO Indonesia-Malaysia dan daya saing ekspor minyak goreng sawit, margarin dan sabun Indonesia dan penerimaan devisa ekspor CPO, minyak goreng sawit, margarin dan sabun Indonesia periode 2015-2017.
Berdasarkan Tabel 7, kondisi sebelum adanya perubahan, Indonesia dan Malaysia memiliki daya saing yang tinggi atau memiliki keunggulan komparatif dalam mengekspor CPO ke sepuluh negara importir utama yang ditunjukkan nilai indeks RCA Indonesia dan Malaysia lebih besar dari 1. Begitu juga Yanita et al. (2019), CPO Indonesia memiliki daya saing komparatif di pasar global dengan tren peningkatan dari tahun 1998 hingga 2017, dimana ratarata nilai RCA sebesar 60,93. Sementara penelitian Amiruddin (2017) menunjukan bahwa CPO memiliki keunggulan komparatif yang tinggi dengan nilai rata-rata RCA sebesar 64,84, dibandingkan dengan Malaysia dengan nilai rata-rata RCA sebesar 20,35, namun nilai RCA Indonesia memiliki tren yang negatif sedangkan Malaysia memiliki tren yang positif. Berbeda halnya dengan produk turunan sawit, RBD palm olein dan PFAD Indonesia yang memiliki tren yang positif dengan nilai rata-rata RCA sebesar 37,85 dan 18,62, sedangkan Malaysia memiliki tren yang negatif dengan nilai rata-rata RCA 38,00 dan 22,22 .

Indonesia lebih unggul daripada Malaysia dalam daya saing ekspor CPO ke Singapura, Italia, Jerman, dan 
Kenya, sedangkan Malaysia lebih unggul daripada Indonesia dalam daya saing ekspor CPO ke India dan Pakistan (hal ini sejalan dengan Salleh et al. 2016), juga ke Belanda, Spanyol, Tanzania, dan Inggris. Namun berbeda dengan Wahyuningsih et al. (2019), Indonesia memiliki daya saing yang relatif lebih baik untuk pasar India dibandingkan Malaysia. Selanjutnya, berdasarkan Tabel 7 dengan kondisi sebelum adanya perubahan, Indonesia juga memiliki keunggulan komparatif dalam mengekspor minyak goreng sawit, margarin dan sabun ke pasar dunia.

Selanjutnya, jika ada simulasi tunggal yaitu: peningkatan pajak impor CPO oleh India sebesar $100 \%$, hal ini akan menurunkan daya saing ekspor CPO Indonesia ke negara importir utama dunia (kecuali ke Singapura dan Tanzania). Simulasi peningkatan pajak impor CPO oleh India sebesar 100\% akan meningkatkan daya saing ekspor minyak goreng sawit, margarin dan sabun Indonesia ke pasar dunia. Sehubungan dengan menurunnya jumlah ekspor CPO Indonesia ke negara importir utama menyebabkan penurunan penerimaan devisa Indonesia dari ekspor CPO sebesar Rp 545,79 miliar. Sementara itu, peningkatan jumlah ekspor minyak goreng sawit, margarin dan sabun akan meningkatkan penerimaan devisa Indonesia dari ekspor minyak goreng sawit, margarin dan sabun masingmasing sebesar Rp 1,81 miliar, Rp 0,04 miliar dan $\operatorname{Rp~0,002~miliar.~}$

Jika ada simulasi tunggal yaitu: peningkatan kapasitas produksi industri minyak goreng sawit, margarin dan sabun masing-masing sebesar $5 \%$, $10 \%$, dan $40 \%$, serta peningkatan permintaan CPO oleh industri lain sebesar 30\%, hal ini akan meningkatkan daya saing ekspor CPO Indonesia ke negara importir utama dunia (kecuali ke Jerman). Simulasi ini juga meningkatkan daya saing ekspor minyak goreng sawit, margarin dan sabun Indonesia ke pasar dunia. Dari simulasi ini diketahui bahwa jumlah ekspor Indonesia terhadap CPO maupun turunannya adalah meningkat sehingga penerimaan devisa Indonesia dari ekspor CPO, minyak goreng sawit, margarin dan sabun meningkat masingmasing sebesar $R p \quad 27,75$ miliar, Rp 723,44 miliar, Rp 19,27 miliar dan Rp 4,54 miliar.

Adapun simulasi kombinasi yaitu: peningkatan pajak impor CPO oleh India sebesar $100 \%$ dan adanya peningkatan kapasitas produksi industri minyak 
goreng sawit, margarin dan sabun masing-masing sebesar $5 \%, 10 \%$, dan $40 \%$, serta peningkatan permintaan CPO oleh industri lain sebesar $30 \%$, hal ini akan meningkatkan daya saing ekspor minyak goreng sawit, margarin dan sabun Indonesia ke pasar dunia. Namun simulasi kombinasi ini menyebabkan penurunan daya saing ekspor CPO Indonesia ke negara importir utama dunia (kecuali ke India, Singapura, Tanzania dan Pakistan). Simulasi kombinasi ini menyebabkan penurunan penerimaan devisa Indonesia dari ekspor CPO sebesar Rp 517,94 miliar, namun simulasi kombinasi ini meningkatkan penerimaan devisa Indonesia dari ekspor minyak goreng sawit, margarin dan sabun masing-masing sebesar Rp 725,24 miliar, Rp 19,31 miliar dan Rp 4,55 miliar. Ini berarti total penerimaan devisa Indonesia masih meningkat sebesar Rp 231,17 miliar.

Hal ini menunjukkan bahwa jika pemerintah ingin mencari alternatif solusi dalam menghadapi hambatan perdagangan berupa tarif impor CPO oleh India maupun negara importir utama lainnya maka kebijakan yang sebaiknya ditempuh terutama dalam jangka panjang adalah dengan memfasilitasi para pengusaha produk turunan CPO dalam meningkatkan kapasitas produksinya.

\section{Tabel 7. Dampak Perubahan Faktor Eksternal dan Kebijakan Domestik terhadap Daya Saing dan Penerimaan Devisa Ekspor CPO dan Produk Turunan Indonesia Periode 2015-2017}

\begin{tabular}{|c|c|c|c|c|c|c|}
\hline \multirow{2}{*}{ No } & \multirow{2}{*}{ Indikator } & \multirow{2}{*}{ Keterangan } & \multirow{2}{*}{ Nilai Dasar } & \multicolumn{3}{|c|}{ Perubahan } \\
\hline & & & & S1 & S2 & S3 \\
\hline 1 & RCAPOIID & RCA-Ekspor CPO Indonesia ke India & 16.4996 & -0.0016 & 0.0062 & 0.0046 \\
\hline 2 & RCAPOMID & RCA-Ekspor CPO Malaysia ke India & 16.7888 & 0.0119 & -0.0083 & 0.0036 \\
\hline 3 & RCAPOINE & RCA-Ekspor CPO Indonesia ke Belanda & 35.8121 & -0.2025 & 0.0296 & -0.1734 \\
\hline 4 & RCAPOMNE & RCA-Ekspor CPO Malaysia ke Belanda & 38.0495 & -0.0243 & -0.0336 & -0.0581 \\
\hline 5 & RCAPOISI & RCA-Ekspor CPO Indonesia ke Singapura & 35.6111 & 0.1176 & 0.0288 & 0.1465 \\
\hline 6 & RCAPOMSI & RCA-Ekspor CPO Malaysia ke Singapura & 1.0849 & -0.0020 & 0.0011 & -0.0009 \\
\hline 7 & RCAPOIIT & RCA-Ekspor CPO Indonesia ke Italia & 136.0629 & -0.2654 & 0.1096 & -0.1543 \\
\hline 8 & RCAPOMIT & RCA-Ekspor CPO Malaysia ke Italia & 129.8661 & 0.2964 & -0.2273 & 0.0683 \\
\hline 9 & RCAPOISP & RCA-Ekspor CPO Indonesia ke Spanyol & 79.8469 & -0.1445 & 0.0973 & -0.0470 \\
\hline 10 & RCAPOMSP & RCA-Ekspor CPO Malaysia ke Spanyol & 112.3635 & -0.1619 & -0.1857 & -0.3467 \\
\hline 11 & RCAPOIGE & RCA-Ekspor CPO Indonesia ke Jerman & 81.5148 & -0.7060 & -0.0173 & -0.7225 \\
\hline 12 & RCAPOMGE & RCA-Ekspor CPO Malaysia ke Jerman & 5.1413 & -0.0305 & -0.0062 & -0.0367 \\
\hline 13 & RCAPOITZ & RCA-Ekspor CPO Indonesia ke Tanzania & 23.6488 & 0.0025 & 0.0078 & 0.0102 \\
\hline
\end{tabular}




\begin{tabular}{|c|c|c|c|c|c|c|}
\hline \multirow{2}{*}{ No } & \multirow{2}{*}{ Indikator } & \multirow{2}{*}{ Keterangan } & \multirow{2}{*}{ Nilai Dasar } & \multicolumn{3}{|c|}{ Perubahan } \\
\hline & & & & S1 & S2 & S3 \\
\hline 14 & RCAPOMTZ & RCA-Ekspor CPO Malaysia ke Tanzania & 30.7678 & 0.0989 & 0.0068 & 0.1057 \\
\hline 15 & RCAPOIUK & RCA-Ekspor CPO Indonesia ke Inggris & 21.8026 & -0.1336 & 0.0481 & -0.0853 \\
\hline 16 & RCAPOMUK & RCA-Ekspor CPO Malaysia ke Inggris & 22.1095 & -0.1730 & -0.0207 & -0.1936 \\
\hline 17 & RCAPOIKE & RCA-Ekspor CPO Indonesia ke Kenya & 6.7183 & -0.0106 & 0.0027 & -0.0079 \\
\hline 18 & RCAPOMKE & RCA-Ekspor CPO Malaysia ke Kenya & 3.6033 & -0.0242 & -0.0024 & -0.0265 \\
\hline 19 & RCAPOIPK & RCA-Ekspor CPO Indonesia ke Pakistan & 3.3323 & -0.0098 & 0.0180 & 0.0084 \\
\hline 20 & RCAPOMPK & RCA-Ekspor CPO Malaysia ke Pakistan & 31.9510 & 0.1591 & -0.0170 & 0.1422 \\
\hline 21 & RCAMGIW & $\begin{array}{l}\text { RCA-Ekspor Minyak Goreng Sawit } \\
\text { Indonesia ke Dunia }\end{array}$ & 54.4250 & 0.0003 & 0.1221 & 0.1224 \\
\hline 22 & RCAMRIW & RCA-Ekspor Margarin Indonesia ke Dunia & 4.7713 & 0.0002 & 0.1039 & 0.1041 \\
\hline 23 & RCASBIW & RCA-Ekspor Sabun Indonesia ke Dunia & 9.8836 & 0.0000 & 0.0098 & 0.0098 \\
\hline 24 & RXPOIW & $\begin{array}{l}\text { Penerimaan Devisa Ekspor } \\
\text { CPO Indonesia (Rp Milyar) }\end{array}$ & $58,266.5295$ & -545.7885 & 27.7467 & -517.9362 \\
\hline 25 & RXMGIW & $\begin{array}{l}\text { Penerimaan Devisa Ekspor Minyak Goreng } \\
\text { Sawit Indonesia (Rp Milyar) }\end{array}$ & $135,896.0501$ & 1.8056 & 723.4405 & 725.2444 \\
\hline 26 & RXMRIW & $\begin{array}{l}\text { Penerimaan Devisa Ekspor Margarin } \\
\text { Indonesia (Rp Milyar) }\end{array}$ & 841.2193 & 0.0350 & 19.2715 & 19.3065 \\
\hline 27 & RXSBIW & $\begin{array}{l}\text { Penerimaan Devisa Ekspor Sabun } \\
\text { Indonesia (Rp Milyar) }\end{array}$ & $4,107.5961$ & 0.0024 & 4.5499 & 4.5523 \\
\hline
\end{tabular}

Keterangan:

RCA : Revealed Comparative Advantage

S1 : Peningkatan pajak impor CPO India sebesar $100 \%$.

S2 : Peningkatan kapasitas produksi industri minyak goreng sawit, margarin dan sabun masingmasing sebesar $5 \%, 10 \%$, dan $40 \%$, serta peningkatan permintaan CPO oleh industri lain sebesar $30 \%$.

S3 : Kombinasi skenario 1 (S1) dan skenario 2 (S2).

Selain itu, kebijakan pemerintah memfasilitasi peningkatan kapasitas produksi industri turunan CPO akan meningkatkan daya saing produk turunan CPO yang akhirnya meningkatkan ekspor dan penerimaan devisa Indonesia dari ekspor produk turunan CPO.

\section{KESIMPULAN DAN REKOMENDASI KEBIJAKAN}

Berdasarkan hasil dan pembahasan, dapat disimpulkan bahwa (1) harga ekspor CPO Indonesia ke India dipengaruhi dan elastis dalam jangka pendek dan jangka panjang terhadap perubahan harga CPO dunia, sehingga dalam jangka pendek dan jangka panjang peningkatan harga CPO dunia akan berpengaruh besar terhadap harga ekspor CPO Indonesia ke India; (2) Permintaan CPO sebagai bahan baku industri minyak goreng sawit, margarin dan sabun dipengaruhi dan elastis dalam jangka panjang terhadap kapasitas produksi industri produk turunan $\mathrm{CPO}$, sehingga dalam jangka panjang peningkatan kapasitas produksi industri hilir CPO akan 
berpengaruh besar terhadap permintaan CPO dan produksi produk turunannya; (3) Jika pajak impor CPO India meningkat dan di dalam negeri kapasitas produksi industri minyak goreng sawit, margarin, sabun dan permintaan CPO oleh industri lainnya meningkat berdampak terhadap peningkatan daya saing dan penerimaan devisa ekspor minyak goreng sawit, margarin dan sabun tetapi daya saing dan penerimaan devisa ekspor CPO menurun. Simulasi kombinasi ini menyebabkan peningkatan nilai penerimaan devisa Indonesia dari ekspor minyak goreng sawit, margarin dan sabun yang lebih besar daripada penurunan nilai penerimaan devisa Indonesia dari ekspor CPO.

Dari kesimpulan tersebut, maka untuk meningkatkan permintaan CPO oleh industri hilir CPO di Indonesia maka pemerintah harus terus meningkatkan fasilitasi bagi pengusaha dalam meningkatkan kapasitas produksi industri hilir CPO. Pemerintah meningkatkan fasilitasi untuk pengembangan industri hilir CPO dengan pemberian insentif investasi pada industri hilir CPO melalui instrumen seperti: tax allowance, tax holiday, dan pembebasan bea masuk atas impor mesin serta barang dan bahan untuk pembangunan industri hilir.

Untuk meningkatkan daya saing dan nilai penerimaan devisa Indonesia dari ekspor produk turunan CPO maka dalam jangka panjang pemerintah harus terus meningkatkan fasilitasinya dalam investasi industri hilir CPO agar produksi dan ekspor produk turunan CPO meningkat.

Untuk mengantisipasi peningkatan pajak impor CPO oleh India maupun negara importir utama lainnya atau hambatan impor lainnya dari importir CPO, para pengusaha CPO dapat meningkatkan penjualan di pasar domestik karena permintaan CPO oleh industri hilir sudah meningkat sebagai hasil kebijakan fasilitasi yang meningkatkan kapasitas produksi industri hilir CPO.

Untuk akademisi disarankan
melakukan penelitian lanjutan
mengenai analisis dampak peningkatan investasi atau kapasitas produksi industri hilir CPO Indonesia terhadap kinerja subsektor perkebunan, kinerja subsektor agroindustri, pertumbuhan ekonomi Indonesia, pengurangan pengangguran dan pengentasan kemiskinan. 
UCAPAN TERIMA KASIH

Penulis mengucapkan terima kasih kepada Direktorat Jenderal Pendidikan Tinggi Republik Indonesia yang telah mendukung studi program doktor dengan dana beasiswa dan penelitian disertasi BPPDN pada 2015 hingga 2018. Penulis juga mengucapkan terima kasih kepada Sekolah Pascasarjana IPB yang memberikan rekomendasi untuk permohonan perpanjangan beasiswa selama satu tahun ke Direktorat Jenderal Pendidikan Tinggi Republik Indonesia.

\section{DAFTAR PUSTAKA}

Amiruddin A. (2017). Analisis daya saing dan dinamika ekspor produk kelapa sawit Indonesia dalam perdagangan internasional [tesis]. Bogor (ID): Institut Pertanian Bogor.

Awad, A., F.M. Arshad, M.N. Shamsudin, dan Z. Yusof. (2007). The Palm Oil Import Demand in Middle East and North African (MENA) Countries. Journal of International Food \& Agribusiness Marketing, Vol 19 (2-3), pp.143-169. doi:10.1300/j047v19n02_08.

[BPPMD] Badan Perijinan dan Penanaman Modal Daerah Provinsi Kalimantan Timur. (2010). Pengembangan Industri Hilir/Oleokimia Dasar Berbasis Minyak Sawit di Kalimantan Timur. Samarinda: BPPMD Provinsi Kalimantan Timur.

[BPS] Badan Pusat Statistik. (2018). Statistik Indonesia 2018. Jakarta: Badan Pusat Statistik.

[CIC] Capricorn Indonesia Consult Inc. (2019). Study and Directory on Palm
Oil Industry in Indonesia. Jakarta: CIC Inc.

Destiarni, RP., S.R. Triyasari, dan A.S. Jamil. (2021). The Determinants of Indonesia's CPO Export in NonTraditional Market. E3S Web of Conferences. 232.02017. 10.1051/e3sconf/202123202017.

[Ditjenbun] Direktorat Jenderal Perkebunan Kementerian Pertanian. (2019). Statistik Perkebunan Indonesia Komoditas Kelapa Sawit Tahun 20072018. Jakarta: Ditjenbun Kementerian Pertanian.

[Ditjen Industri Agro] Direktorat Jenderal Industri Agro Kementerian Perindustrian. (2015). Strategi Percepatan Diversifikasi Industri Hilir Kelapa Sawit. Makalah: Disajikan pada Palm Oil Industry Development Conference pada tanggal 9-10 September 2015 di Jakarta.

Ernawati, Fatimah, M. Arshad, M.N. Shamsudin, dan Z.A. Mohamed. (2006). AFTA and Its Implication to The Export Demand of Indonesian Palm Oil. Jurnal Agro Ekonomi, Vol 24 (2), pp.115-132. doi:10.21082/jae.v24n2.2006.115132.

[GAPKI] Gabungan Pengusaha Kelapa Sawit Indonesia. (2017). Kemajuan Hilirisasi Minyak Sawit Indonesia. GAPKI news. Diunduh tanggal 3 Agustus 2020 dari https://gapki.id/news/2476/kemajuanhilirisasi-minyak-sawit-indonesia.

Mukherjee, I., dan B.K. Sovacool. (2014). Palm Oil-Based Biofuels and Sustainability in Southeast Asia: A Review of Indonesia, Malaysia, and Thailand. Renewable and Sustainable Energy Reviews, Vol 37, pp.1-12. doi:10.1016/j.rser.2014.05.001.

Negoro, HA., H Herdiansyah, R Sari, M.A. Munandar, dan J.T. Haryanto. (2020). India's Tariff on CPO and CPO Price: Why Tariff Matters More than Price on Indonesia's CPO. 10.21203/rs.3.rs56132/v1. 
Novindra. (2011). Dampak Kebijakan Domestik dan Perubahan Faktor Eksternal terhadap Kesejahteraan Produsen dan Konsumen Minyak Sawit di Indonesia. Tesis. Bogor: Sekolah Pascasarjana Institut Pertanian Bogor.

Novindra, B.M. Sinaga, dan D.S. Priyarsono. (2013). Dampak Kebijakan Pajak Ekspor Minyak Sawit dan Domestic Market Obligation pada Kesejahteraan Konsumen Minyak Sawit di Indonesia. Dalam: M. Firdaus, A Rifin, Sahara, Novindra, dan M. Syaefudin (Eds). Orange Book $\checkmark$ Ekonomi dan Manajemen: Ketahanan Pangan. Bogor: IPB Press. pp.197-213.

Novindra, B.M. Sinaga, S. Hartoyo, dan Erwidodo. (2019). Impact of Domestic Policies and External Factors on The Competitiveness and Crude Palm Oil Industry Actor's Welfare in Indonesia. International Journal of Science and Research, Vol 8(8), pp.498-503. doi:10.21275/ART2020153.

Nurcahyani, M., Masyhuri, dan S. Hartono. (2018). The Export Supply of Indonesian Crude Palm Oil (CPO) to India. AGRO EKONOMI, Vol 29(1), Hal.18-31. doi:10.22146/ae.29931.

Nurmalita, V., dan P.A. Wibowo. (2019). Analisis Faktor-Faktor yang Mempengaruhi Ekspor Minyak Kelapa Sawit Indonesia ke India. Economic Education Analysis Journal (EEAJ), Vol 8(2), Hal.605-619. doi:10.15294/eeaj.v8i2.31492.

Oil World. (2018). 17 Oils Fats and Biodiesel. Langenberg, Hamburg: ISTA Mielke $\mathrm{GmbH}$.

Purba, H.J. (2019). Dampak faktor eksternal dan internal terhadap pasar minyak nabati dunia dan biodiesel Indonesia [disertasi]. Bogor (ID): Institut Pertanian Bogor.

Rifai, N. (2014). Evaluasi Kebijakan Ekonomi Ekspor Minyak Sawit dan Produk Turunannya ke Pasar Amerika Serikat. Disertasi. Bogor:
Sekolah Pascasarjana Institut Pertanian Bogor.

Salleh, K.M., R. Abdullah, M.A.K Ab Rahman, N. Balu, dan A.Z.A. Nordin. (2016). Revealed Comparative Advantage and Competitiveness of Malaysian Palm Oil Exports Againts Indonesia in Five Major Markets. Oil Palm Industry Economic Journal, Vol 16 (1), pp.1-7.

Sally, M. (2019). US Sanctions on Iran, Rising Brent Rates May Raise Edible Oil Prices. Diunduh tanggal 1 November 2019 dari https://economictimes.indiatimes.com /markets/commodities/news/ussanctions-on-iran-rising-brent-ratesmay-raise-edible-oilprices/articleshow/69000643.cms?ut m_source $=$ contentofinterest\&utm_me dium=text\&utm_campaign=cppst.

Simanjuntak D.N. (2014). 2015, Indonesia Hasilkan 169 Produk Turunan Sawit. INVESTOR DAILY. Diunduh tanggal 30 Juli 2020 dari https://investor.id/agribusiness/2015indonesia-hasilkan-169-produkturunan-sawit.

Sitanggang, T. (2018). Indonesia Palm Oil Supply and Demand. Makalah: Disajikan pada Indonesian Palm Oil Conference pada tanggal 31 Oktober2 November 2018 di Bali.

[UN Comtrade] United Nations Commodity Trade. (2019). UN Comtrade Statistics Database. Diunduh tanggal 9 Juli 2019 dari http://comtrade.un.org/data/.

Wahyuningsih, S.N., Budiarto, Juarini. (2019). Analisis daya saing dan trend ekspor CPO Indonesia di Pasar India dan China. Jurnal Dinamika Sosial Ekonomi. 20(1):1-13.

World Bank. (2019). World Bank Commodities Price Data. Diunduh tanggal 15 Agustus 2020 dari http://www.worldbank.org/commoditie s.

[WTO] World Trade Organization. (2019). WTO: Tariff Analysis Online. Diunduh 
tanggal 9 Juli 2019 dari http://tao.wto.org/report/TariffLines.as px.

Yanita, M., D.M. Napitupulu, dan K. Rahmah. (2019). Analysis of Factors
Affecting the Competitiveness of Indonesian Crude Palm Oil (CPO) Export in the Global Market. Indonesian Journal of Agricultural Research, Vol 2(3), Hal.156-169. doi:10.32734/injar.v2i3.2857. 
104 | Buletin IImiah Litbang Perdagangan, VOL.15 NO.1, JULI 2021 